\title{
Reconciling the Firm Size and Innovation Puzzle
}

by

\author{
Anne Marie Knott \\ Washington University
}

\author{
Carl Vieregger \\ University of Illinois
}

\begin{abstract}
CES 16-20
March, 2016

The research program of the Center for Economic Studies (CES) produces a wide range of economic analyses to improve the statistical programs of the U.S. Census Bureau. Many of these analyses take the form of CES research papers. The papers have not undergone the review accorded Census Bureau publications and no endorsement should be inferred. Any opinions and conclusions expressed herein are those of the author(s) and do not necessarily represent the views of the U.S. Census Bureau. All results have been reviewed to ensure that no confidential information is disclosed. Republication in whole or part must be cleared with the authors.

To obtain information about the series, see www.census.gov/ces or contact Fariha Kamal, Editor, Discussion Papers, U.S. Census Bureau, Center for Economic Studies 2K132B, 4600 Silver Hill Road, Washington, DC 20233, CES.Papers.List@census.gov. To subscribe to the series, please click here.
\end{abstract}




\begin{abstract}
Since Schumpeter, there has been a long-standing debate regarding the optimal firm size for innovation. Empirical results have settled into a puzzle: R\&D spending increasing with scale while R\&D productivity decreases with scale. Thus large firms appear irrational. We propose the puzzle stems from the fact that product and patent counts undercount large firm innovation. To test that proposition we use recently available NSF BRDIS survey data of firms R\&D practices as well as a broader measure of R\&D productivity. Using the broader measure, we find that both $R \& D$ spending and $R \& D$ productivity increase with scale-thus resolving the puzzle. We further find that while large firms and small firms differ in the types of R\&D they conduct, there is no type whose returns decrease in scale - there are merely types for which the small firm penalty is less severe.
\end{abstract}

Knott: Washington University, One Brookings Drive, Campus Box 1133, St Louis, MO 63130 (email:knott@wustl.edu), Vieregger: University of Illinois 350 Wohlers Hall,1206 South Sixth Street, Champaign, IL 61820 (email: chv@illinois.edu). We gratefully acknowledge support under NSF Award 1246893: The Impact of R\&D Practices on R\&D Effectiveness. DISCLAIMERS: Any opinions and conclusions expressed herein are those of the author(s) and do not necessarily represent the views of the U.S. Census Bureau. All results have been reviewed to ensure that no confidential information is disclosed. One author has a financial interest in amkANALYTICS, a subscription database of firm RQs. 


\section{Introduction}

The firm size and R\&D hypothesis is one of the two main hypotheses in innovation economics, the other being market structure. Both hypotheses are attributed to Schumpeter (1942) who asserted that large firms are the major engine of economic growth. The most important advantage of size is scale economies--at a minimum, larger scale amortizes the fixed cost per innovation over a larger number of units. Accordingly, the returns to innovation should be greater for large firms. This then is an argument about ability to exploit innovation.

A companion argument considers the impact of firm size on ability to conduct R\&D. On one side of the argument, large firms are viewed to be more effective with their R\&D. This could occur for a number of reasons. First, there may be minimum efficient scales for some $R \& D$ projects, e.g., there is only one super-collider. Second, $R \& D$ projects are known to be stochastic. Stevens and Burley (1997) report that on average for Industrial Research Institute (IRI) member firms, it takes 125 funded projects to achieve one commercial success. Large firms are better able to absorb this risk because they can pool it over a broader portfolio of projects. Having a broad portfolio confers another advantage: technical diversity — typically more projects implies a broader set of problems and associated expertise (Nelson 1959). This increases the likelihood of having any required expertise in-house. Finally, large scale implies a broader set of product markets. Drawing again upon the stochastic nature of R\&D, this increases the likelihood that projects that fail for a given application, might have other applications elsewhere in the firm.

On the flip side of the size debate are arguments suggesting small firms are more productive with their R\&D. Indeed colloquially, people use the term “entrepreneurial” (conveying small start-up firms) to connote innovativeness. The small firm arguments typically rely on governance advantages. Having fewer employees implies decision makers are closer both to the technology as well as the customer, thus they can better link technological possibilities to market needs. Horizontally, fewer employees implies closer proximity between technical workers, which facilitates problem solving (Allen 1977). Vertically, small firms have fewer levels of hierarchy, so decision-making can be more rapid. Finally, small technology firms tend to be younger, so are less prone to organizational rigidities (Leonard-Barton 1992). 
Thus there appear to be compelling arguments for either size to be more effective in conducting R\&D. This likely explains why both large and small firms conduct R\&D. If either size had a substantial advantage, the other size would be unlikely to conduct R\&D. Accordingly, more recent theories attempt to reconcile the co-existence of large firm and small firm R\&D. These theories suggest the two sizes differ in the type of R\&D they conduct, and that the returns to type vary with firm size. In essence they argue that choice of R\&D strategy is endogenous-firms choose the strategy most likely to be effective given their size. Nelson (1959) for example, argues that large firms are more likely to conduct basic research because they have a broader technological base, as well as a wider range of products they are willing to produce if the research identifies opportunities. Rosen (1991) develops a model that explains the tendency of radical innovation to decrease with firm size (Mansfield's 1981). Firms in the model separately choose project riskiness and project scale. Because the scale of their output is greater, large firms prefer safer innovation that enhances their existing technology. In contrast, because they lack scale, small firms require riskier projects that have the potential for greater price-cost margins. Finally, Cohen and Klepper (1996) develop a model to explain the tendency for process R\&D to increase with firm size (Scherer 1991). Because process innovation provides lower cost good/services to existing customers, the returns to process innovation increase in the ex ante output. In contrast, returns to product innovation stem from licensing or sales to new customers, thus are independent of ex ante output. Accordingly large firms favor process innovation, while small firms favor product innovation.

While there is a substantial empirical literature testing the size hypothesis (see Cohen 2010 for a summary), that literature has been unable to resolve the debate. Indeed the stylized facts introduce a puzzle. Tests of innovative behavior indicate that $R \& D$ investment increases with scale, e.g., Baldwin and Scott 1987, Scherer and Ross 1990. However, studies of innovative outcomes tend to find small firms are more productive, e.g., Scherer 1965, Pavitt et al 1987, Acs and Audretsch 1988, 1990. Accordingly, we are left with the puzzle of seemingly irrational behavior of large firms: R\&D investment increases in scale, despite the fact that $R \& D$ productivity appears to decrease with scale.

One possible explanation for the empirical puzzle is that the outcome studies rely on product counts or patent counts as the measure of $R \& D$ outcomes. If choice of $R \& D$ strategy is endogenously determined by firm size as the more recent theories suggest, these tests may 
undercount large firm innovation, since it is disproportionately process and/or incremental (which is less likely to be patented). Thus to resolve the puzzle, we need empirics that account for the endogenous choice of R\&D strategy. This in turn requires data on R\&D practices as well as a more comprehensive measure of productivity that captures all forms of R\&D.

We exploit recently available NSF BRDIS survey data to solve the former problem and a recent measure of R\&D productivity, RQ (short for Research Quotient), to solve the latter problem, in an effort to resolve the firm size puzzle. With these new data and measure we find that both $R \& D$ spending and $R \& D$ productivity increase with scale (thus large firms are rational). We further find that while $R \& D$ strategy is endogenously determined by firm size (in accordance with theory), we could find no strategy favoring small firms. In particular, there are no strategies whose returns decrease in scale-there are merely strategies for which the small firm penalty is less severe. This prompts a second question: why then do small firms conduct R\&D? A preliminary answer appears to be they rely more heavily on spillovers from large firms. Thus not only do large firms provide the bulk of innovation in the economy, they provide the spillovers that subsidize small firm innovation.

\section{Empirical Approach}

This study is an effort to resolve the firm size puzzle by testing the more nuanced theories of firm size and R\&D. To do so we exploit recently collected data on firms’ R\&D practices from the National Science Foundation (NSF) Business R\&D and Innovation Survey (BRDIS) as well as a recent measure of R\&D effectiveness, RQ, that captures all forms of R\&D.

\section{BRDIS Data}

BRDIS is an annual survey of firms' R\&D behavior conducted by the National Science Foundation (NSF) in conjunction with the U.S Census Bureau. BRDIS is a more expansive successor to the Survey of Industrial Research and Development (SIRD), which was conducted from fiscal years 1953 to 2007. Both surveys address the industry component of the NSF mandate "...to provide a central clearinghouse for the collection, interpretation, and analysis of data on scientific and engineering resources and to provide a source of information for policy 
formulation by other agencies of the Federal government."

The more expansive survey was deemed necessary because the bulk of R\&D is now funded by industry, whereas in the 1950s, when the SIRD was created, the majority of R\&D was funded by the US government. Thus greater insight into firm R\&D behavior was warranted. In addition, the new survey better matches the Community Innovation Survey (CIS) conducted by the EU countries. Accordingly, BRDIS data supports comparisons of innovative behavior between the US and other countries.

BRDIS is mailed annually to approximately 40,000 companies. The BRDIS sample is intended to represent the approximately 1.5 million for-profit companies in the United States with five or more domestic employees, both publicly or privately held. The overall response rate in the 2008 survey was $77.4 \%$, and the response rate for the top 500 domestic R\&Dperforming companies was $92.6 \%$. Of these responding firms, approximately $3 \%$ reported performing and/or funding R\&D.

BRDIS gathers data on a number of R\&D variables. The full surveys for each year are available at http://www.nsf.gov/statistics/srvyindustry/\#qs, however we focus attention on the variables related to firm size, firm R\&D strategy, as well as financials required to derive firm RQ. With regard to the strategy variables, we examine the three R\&D strategies hypothesized to affect or be affected by scale:

1) Portfolio horizon (capturing Nelson 1959): "What percentage of R\&D paid for and performed by your company was for:

a. Basic research: planned, systematic pursuit of new knowledge without specific immediate commercial application

b. Applied research: planned, systematic pursuit of new knowledge aimed at solving a specific problem or meeting a specific commercial objective c. Development: the systematic use of research and practical experience to produce new or significantly improved goods, services or processes”.

2) Riskiness (capturing Rosen 1991): "What percentage of this year's sales were from goods/services introduced in the past three years that were:

a. New (or significantly improved) to your market 

b. New (or significantly improved) only to your company
c. Unchanged or only marginally modified"

3) Locus (capturing Cohen and Klepper 1996): "Did your company introduce any of the following in the prior three years:
a. New (or significantly improved) goods
b. New (or significantly improved) services
c. New (or significantly improved) processes (methods of producing goods or services, distributions systems for inputs or outputs of your goods or services, support activities)"

\section{RQ estimation}

$\mathrm{RQ}$ is the firm-specific output elasticity of R\&D in the firm's production function (Knott 2008). Thus it represents the percentage increase in revenues from a $1 \%$ increase in R\&D, holding constant other inputs and their elasticities. Accordingly, RQ conforms with the most common means to measure returns to R\&D at the industry and economy levels (Hall, Mairesse and Mohnen 2010). Where RQ departs from prior estimation of returns to R\&D is that it captures them at the firm-level rather than at the industry or economy level. This departure stems from both the realization there is substantial firm heterogeneity even within an industry (see Syverson 2011 for a review), and the availability of data and methods to estimate firm-level elasticities. Tests of RQ versus two other proxies for R\&D productivity (patent intensity and TFP) indicate RQ is the only measure empirically consistent with expectations from firm-level endogenous growth theory (Thompson 1996, Lentz and Mortensen 2011) that R\&D, growth and market value increase in R\&D productivity (Knott and Vieregger 2015). Of course, RQ has limitations. In particular, it can only capture innovation derived from R\&D. Thus it excludes innovation by the approximately 7\% of non-R\&D firms who report introducing product or service innovations in the prior three years (Boroush 2010).

We derive RQ using random coefficients estimation of the firm's production function (Equation 1) in accordance with the general methodology described in Knott (2008). One complication with estimation using the BRDIS data is that its input variables differ from those collected from firms'10-K filings (the source for Compustat data on which the RQs in Knott 
(2008) were derived). While revenues, employees and R\&D expenditures are the same in both datasets, BRDIS collects capital expenditures rather than property, plant and equipment, and does not collect advertising. Accordingly we employ a model of the following form:

$$
\begin{aligned}
\ln Y_{i t}= & \left(\beta_{0}+\beta_{0 i}\right)+\left(\beta_{1}+\beta_{1 i}\right) \ln K_{i t}+\left(\beta_{2}+\beta_{2 i}\right) \ln L_{i t}+\left(\beta_{3}+\beta_{3 i}\right) \ln R_{i t-1} \\
& +\left(\beta_{4}+\beta_{4 i}\right) \ln S_{i t-1}+\varepsilon_{i t}
\end{aligned}
$$

Firm level data items include (in \$MM unless otherwise stated): revenues (Yit), capital expenditures (Kit), labor as full-time equivalent employees $(1000)\left(L_{i t}\right)$, and $R \& D\left(R_{i t}\right)$. From these primary data, we derive a secondary measure: firm-specific spillovers ( $S_{i t}$ ) which is computed as the sum of the differences in knowledge between focal firm $i$ and rival firm $j$ for all firms in the four digit SIC industry with more knowledge (R\&D) than the focal firm:

$$
S_{i t}=\sum_{j \neq i} R_{j t}-R_{i t} \forall R_{j t} \geq R_{i t}
$$

This construction mimics the spillover construct in endogenous growth models with heterogeneous firms, e.g., Jovanovic and MacDonald 1994. It is a density measure that takes into account the number of firms with superior knowledge as well as the amount of each firm's surfeit of knowledge relative to the focal firm. In essence it represents the likelihood and extent of discovering superior knowledge in a random encounter with a rival firm. Both R\&D and spillovers are lagged one year. ${ }^{1}$

We validated the abbreviated RQ estimation with Compustat data comparing RQs estimated with the full set of inputs in Knott (2008), to those estimated with the restricted set of BRDIS inputs. That comparison indicates that RQs are 91.7\% correlated across the two equations.

A second restriction of the BRDIS data is that is has only been released for years 20082011. Accordingly the maximum window size per RQ estimate is four-years, whereas prior estimates of RQ (Knott 2008, Knott and Vieregger 2015) used seven and ten-year windows. Accordingly, we tested the impact of window size using Compustat data. Comparisons of RQs generated with Compustat data in a window surrounding the year 2000 indicate RQ estimates with a four-year window are $75.8 \%$ correlated with those estimated with seven-year window. Thus the shorter window will make it more difficult for us to obtain significant results. However

\footnotetext{
${ }^{1}$ There is no significant difference between one and two year lags. This finding matches two empirical regularities: econometric equivalence between stock and flow models and econometric equivalence of models with different lags (Griliches and Mairesse 1984, Adams and Jaffe 1996).
} 
if we do obtain significant results, the high correlation makes it likely results will hold and be more significant with the longer window.

Because RQ estimation consumes 4 years data, we have only one observation for RQ (the 4 year mean). Accordingly, we form four-year averages of our scale variables (revenues, employees) and our outcome variables (R\&D and patents) as well as the strategy variables. This yields one observation per firm. Accordingly our analyses are cross-sectional rather than longitudinal. A summary of the resulting dataset is provided in Table 1.

Insert Table 1 about here

Firm Size Tests

Our firm size tests have two components: The main effects of scale, and the choice and impact of R\&D strategy.

Main Effects of scale. We begin firm size testing by examining the main effects of firm scale on behavior (R\&D spending) (equation 3) and outcomes (RQ) (equation 4). If as we expect, firm size drives R\&D strategy, the coefficients on size will be biased in these estimations. Thus the main role of these tests is to generate results that can be compared to prior studies.

$$
\begin{aligned}
& \ln R_{i t}=\beta_{0}+\beta_{1} \ln Y_{i t}+\varepsilon_{i t} \\
& R Q_{i t}=\beta_{0}+\beta_{1} \ln Y_{i t}+\varepsilon_{i t}
\end{aligned}
$$

Choice and Impact of R\&D Strategy. To begin teasing apart how scale drives behavior and outcomes, we next examine R\&D strategy. As mentioned previously, firm R\&D strategy, as captured in the BRDIS data, has three components: portfolio horizon (basic, applied, development), riskiness (new to market, new to firm, incremental), and locus (product, service, process). We examine both the impact of scale on choice of strategy (equation 5) and the impact of strategy on outcomes (equation 6).

(5) $\quad P(\text { strategy })_{i}=\beta_{0}+\beta_{1} \ln Y_{i i}+\varepsilon_{i}$

(6) $R Q_{i j}=\beta_{0}+\beta_{1 i}$ strategy $_{j}+\beta_{2} \ln Y_{i t}+\beta_{3 j}$ strategy $_{j} * \ln Y_{i}+\varepsilon_{i}$ 
We estimate equations 5 and 6 for each strategy first by defining strategy as the nine unidimensional choices from the BRDIS questions (three each for horizon, riskiness and locus). However, because it is unlikely firms choose the level of each uni-dimensional strategy in isolation, we also examine whether firms’ R\&D strategies are better characterized as bundles. Accordingly we use cluster analysis to construct strategy “archetypes” for portfolio horizon, riskiness, and locus. We then repeat estimation of equations 5 and 6 replacing the unidimensional strategies with the strategy archetypes.

\section{Results}

Main Effects of Scale. Table 2 presents results for the impact of scale on behavior (R\&D spending) (Models 1-2) as well as outcomes (RQ) (models 3-4). For each test, we examine two alternative measures of firm scale (revenues and employees).

Insert Table 2 about here

Regarding the impact of scale on $R \& D$ investment, results indicate that scale is positive and highly significant. Indeed, scale explains approximately $49 \%$ of intra-firm variance in $R \& D$. The best fitting model is one using $\ln ($ employees) (Model 2). The coefficient estimate of 0.717 implies that a $10 \%$ increase in the number of employees increases R\&D 7.2\%. Thus while R\&D increases with scale, $R \& D$ intensity is decreasing with scale. These results match stylized facts (Cohen 2010).

Regarding the impact of scale on outcomes, we also find scale has a positive and significant impact on RQ. The coefficient estimate of 0.014 implies that a $10 \%$ increase in firm revenues increases $R \& D$ productivity $0.14 \%$. As with $R \& D$ investment, scale explains a substantial portion (41\%) of the variance in RQ.

Thus our results using BRDIS data and the RQ measure yield firm behavior and outcomes that are consistent with one another: $R \& D$ investment and $R \& D$ productivity both increase with scale. While these results resolve the prior puzzle of inconsistency between behavior and returns, the results may be biased by the fact that $R \& D$ strategy varies with size, and that returns to $R \& D$ strategies may also vary with size. Accordingly, we begin to decompose that by looking separately 
at the impact of scale on choice of strategy and the impact of strategy on behavior and outcomes. We look first at the uni-dimensional strategies. We then discuss strategy archetypes, and repeat the tests with the three archetypes.

Choice of Uni-dimensional R\&D strategy. Results for tests of R\&D strategy choice (Table 3) provide support for all three theories of scale-based $R \& D$ strategy. The percentage of $R \& D$ devoted to basic research is increasing in scale (consistent with Nelson 1959). The likelihood of introducing a process innovation is also increasing in scale (consistent with Cohen and Klepper 1996). Note however that the likelihood of introducing product and service innovations is also increasing in scale (though the likelihood of process innovation is 2.5 times that for product innovation). The result that all forms of innovation are increasing in scale likely stems from measure coarseness. The measure equals one if any innovation was introduced in the prior three years. Thus it can't be used to gauge the scale of process $R \& D$ relative to product $R \& D$. Finally, the extent of incremental innovation is increasing in scale, while the extent of radical innovation is decreasing in scale. Both results support Rosen's (1991) theory regarding the impact of scale on the riskiness of $R \& D$.

Insert Table 3 about here

Impact of Strategy on R\&D Outcomes. Having demonstrated that firm R\&D behavior is consistent with theories of strategic choice, we now turn to the question of returns (RQ) to those strategies (Table 4). Each model in Table 4 captures the impact of the strategy identified in the column header. For example, model 1 captures the impact of basic research on RQ. We allow each strategy to have both intercept and slope (with scale) effects. Table 4 reveals that across the set of strategies, the main effects of scale continue to be significant and of similar magnitude to the main model of scale in Table 2 (0.014). While the coefficients on strategy tend to be significant, the signs on the intercept and slope terms consistently have opposite sign. Thus the role of strategy is to slightly rotate the relationship between scale and RQ as shown in Figure 1 for the three horizon strategies. However for all strategies, the net returns to R\&D increase with scale (with slopes ranging from 0.011 for service innovation to 0.022 for development). Accordingly, there is no strategy favoring small firms. Rather there are merely strategies for which the penalty for small 
scale is less severe.

Insert Table 4 about here

Insert Figure 1 about here

Because it is likely that R\&D strategies are more nuanced than the uni-dimensional measures allow, we next allow for the possibility of bundled strategies ("strategy archetypes”).

$\underline{\text { R\&D Strategy archetypes. }}$ We conduct cluster analysis of the three uni-dimensional strategies within each main strategy category (horizon, riskiness and form) to create strategy archetypes. To generate the archetypes, we follow a two-step process. In the first step, we create nine separate groupings, ranging from a minimum of two clusters to a maximum of ten, and compare the Calińsky and Harabasz pseudo-F index across each grouping. Because the F-scores are similar across several groupings, in a second step we examine the content of each grouping in selecting our final cluster sizes. The objective of this second step is to ensure that the automaticallygenerated clusters also conform to observed strategic groupings in management practice. While our reported clusters are based on kmeans partition cluster analysis, we also test groupings based on kmedians, agglomerative hierarchical clustering methods, and the examination of dendograms, which produce qualitatively similar results. The analysis yields five archetypes for horizon, six for riskiness and seven for locus. These archetypes are characterized in Table 5.

Insert Table 5 about here

Table 5a reveals that horizon clustered into five archetypes: BAD1 through BAD5. Each archetype has a fairly intuitive interpretation. BAD1: principally development, with some applied research; BAD2: applied/development balance; BAD3: exclusively development; BAD4: principally basic research; and BAD5: principally applied research. Note that BAD4 and BAD5 are rare, comprising 30 and 60 firms, respectively, while BAD3 is most prevalent (50\% of firms). 
Table 5b reveals that riskiness clustered into six archetypes: OWN1 through OWN6. As with horizon, each archetype has a fairly intuitive interpretation. OWN1: principally new to market; OWN2: principally new to firm; OWN3: new to market/incremental balance; OWN4: New to firm/incremental balance; OWN5: exclusively incremental; OWN6: principally incremental. OWN1 and OWN2 are relatively rare, comprising 90 and 70 firms, respectively, while OWN5 is most prevalent with $47 \%$ of firms.

Finally, Table 5c reveals that locus clustered into seven archetypes: PSP1 through PSP6. As with horizon, each archetype has a fairly intuitive interpretation. PSP1: balance across all types; PSP2: exclusively product; PSP3: exclusively process; PSP4: exclusively service; PSP5:

product/service balance; PSP6: product/process balance; PSP7: service/process balance. PSP3, 4, 6 and 7 are relatively rare, comprising 10, 20, 80 and 60 firms, respectively, while PSP1 is most prevalent with $52 \%$ of firms.

Impact of Scale on Choice of Strategy Archetypes. We replicate the tests of the impact of scale on choice of strategy and the impact of strategy on outcomes replacing the uni-dimensional strategies in Tables 3 and 4 with the strategy archetypes.

Table 6 reveals that firm choice regarding strategy archetypes resembles that for unidimensional strategies in Table 3. In particular, strategies dominated by process (PSP1) and incremental innovation (OWN5) increase with scale, while strategies with substantial radical (OWN1, OWN3) and product innovation (PSP2, PSP5, PSP6) decrease with scale.

Insert Table 6 about here

Impact of Strategy Archetypes on RQ Looking next at the impact of strategy on outcomes (Table 7), we again obtain results similar to those for uni-dimensional strategy in Table 4. In particular, there is no strategy whose returns decrease with scale. There are merely strategies for which the penalty for small scale is less severe.

Insert Table 7 about here 


\section{A New Puzzle}

Our main tests of firm size replicated prior results indicating R\&D spending increases with scale, but conflicted with prior results indicating small firms have higher R\&D productivity. Our results indicate $R \& D$ productivity, like $R \& D$ spending, increases with firm size. Thus large firms are behaving rationally. The difference in our results versus prior results likely stems from use of RQ, an outcome measure that accommodates all forms of R\&D. Prior tests used product/patent counts, which may tend to underweight contributions from the R\&D strategies favored by large firms. Accordingly, our results resolve the first question of the seemingly irrational behavior of large firms. However, the results raise a new question of small firm irrationality: why do small firms conduct R\&D given their lower R\&D productivity?

We have shown the answer lies outside small firm preference for radical and product innovation. The productivity of both strategies increases in scale. One hypothesis we haven't addressed is that small firms benefit disproportionately from spillovers (Acs, Audretsch and Feldman 1994). In empirical test of their hypothesis, the authors found that university R\&D has a 50\% higher effect on innovation counts for small firms than it did for large firms. In contrast, industrial R\&D has the opposite effect (72\% higher coefficient for large firms relative to small firms). Because the test was at the state-technology level, it's difficult to draw conclusions about spillover effects at the firm level. For example, we don't know the extent to which the large firm effect for industrial $R \& D$ reflects own $R \& D$ or spillovers from rival $R \& D$. If the latter, then the contributions of spillovers for large firms may be larger than for small firms since aggregate industrial R\&D exceeds university R\&D. Accordingly, we attempt to resolve the ambiguity regarding spillovers by estimating their size and impact at the firm level for the BRDIS firms.

Spillovers enter the firm's production function (equation 1) through two terms, the size of the spillover pool, $S_{i}$, and the output elasticity of the spillover pool, $(\beta 4+\beta 4 i)$, which we call SQ (short for spillover quotient). Like RQ, SQ reflects the percentage increase in output associated with a $1 \%$ increase in the corresponding R\&D input. Each spillover term $\left(S_{i}, \mathrm{SQ}\right)$ poses potential for differences between small firms and large firms with respect to innovative output. Accordingly, we test the extent to which $S_{i}$ and SQ explain small firm willingness to conduct R\&D. 
Table 8 mimics Table 1, but examines the spillover pool and SQ rather than own R\&D and RQ. Models 1 and 2 indicate the coefficient on scale in the spillover pool regression is negative and significant. Thus small firms have an advantage in the size of the spillover pool they can access. However, this result is largely an artifact of the manner in which spillover pools are constructed. In contrast, Models 3 and 4 indicate the coefficient on scale in the SQ regression is positive and significant. Thus large firms actually are better exploiting spillovers. The net effect of spillovers is therefore increasing in scale (as shown in Figure 2). Thus spillovers (at least as they are captured here) are unable to explain why small firms innovate.

Insert Table 8 about here

Insert Figure 2 about here

\section{Conclusion}

There has been a long-standing debate regarding the impact of firm size on innovation. Stylized facts indicate R\&D spending increases with size, while R\&D productivity decreases with size. This creates a puzzle of large firm irrationality. Existing theoryies pose an explanation for the puzzle, that firm size affects the type of R\&D firms conduct, and that the productivity of types differs with firm size. Until recently, we have been unable to comprehensively test these views because we lacked firm-level data on the type of R\&D firms conduct, and because the most common measures of R\&D outcomes (product and patent counts) embed type.

We exploited recent developments to test these more nuanced views of innovation and firm size. In particular, we utilized a recently created dataset (BRDIS) to solve the data availability problem and a recent measure of $R \& D$ productivity (RQ) to solve the measurement problem. The BRDIS data and the RQ measure allowed us to conduct a series of tests examining the 
relationship between firm size, R\&D strategy, and R\&D outcomes (RQ).

We found first that R\&D spending and R\&D productivity both increase with firm size. This in itself reconciles the puzzle of large firm irrationality. While the spending result is consistent with prior studies, the productivity result conflicts with them. We believe the conflict stems from the fact that prior results rely upon "type-specific" (product and patent count) measures of $R \& D$ productivity that undercount $R \& D$ done by large firms. We can't test this however because we lack a means to link patent data on private firms to the anonymous firms in BRDIS.

We found second that firm size does indeed affect choice of R\&D strategy as expected in theories proposed by Nelson (1959), Rosen (1991) and Cohen \& Klepper (1996). All three theories correctly anticipated the strategies preferred by large firms. In particular, scale increased the likelihood of incremental R\&D (consistent with Rosen, 1991), process R\&D (consistent with Cohen and Klepper, 1996) and basic research (consistent with Nelson 1959). However, we also found scale increased the likelihood of product and service R\&D—indeed the most likely large firm "locus" strategy was a balance across product/service/process. While this result differs slightly from Cohen and Klepper (who found that the share of process R\&D increases then decreases with firm size), the difference likely stems from the fact that the BRDIS measures for type are fairly crude: "did you introduce an innovation (of the given type) in past three years?" In contrast Cohen and Klepper measure the extent of product and process R\&D.

Despite the fact that the theories were correct regarding the relationships between firm size and R\&D strategy, we found that none of the small firm strategies favored small firms - the productivity of all strategies increased with scale. Rather, there were merely strategies that penalized small scale less. This posed a new puzzle, "why do small firms conduct R\&D?”

We could identify only one other factor that might account for small firms conducting R\&D — that they benefit disproportionately from spillovers. We explored that possibility by characterizing the impact of scale on both the size of a firm's spillover pool and the elasticity of output with respect to that spillover pool. We found that the size of the spillover pool decreases with scale, but that the elasticity of the pool increases with scale. Thus small firms do appear to have one advantage relative to large firms-larger spillover pools, but the net effect of spillovers increases with scale. This still leaves the puzzle of small firm R\&D. 
Beyond reconciling the first puzzle of irrational large firms, and providing preliminary insight into the second puzzle of why small firms conduct R\&D, our results offer a broader implication: that large firms are the chief engine of innovation (and accordingly economic growth). Thus Schumpeter (1942) was correct. Not only do large firms (using the US Small Business Association definition of greater than 500 employees) conduct 5.75 more R\&D in aggregate than small firms, they have 13\% higher productivity with that R\&D. However this merely captures the private returns to their R\&D. A further benefit of large firm R\&D is that it generates the spillovers upon which small firm innovation free-rides. 


\section{REFERENCES}

Acs, Z. and D. Audretsch 1988. "Innovation in Large and Small Firms: An Empirical Analysis”, American Economic Review, 78 (4): 678-690.

Acs, Z. and D. Audretsch 1990. Innovation and Small Firms, Cambridge: MIT Press

Acs, Z., D. Audretsch and M. Feldman 1994. "R\&D Spillovers and Recipient Firm Size" Review of Economics and Statistics, 336-340.

Allen, T. 1977 Managing the Flow of Technology: Technology Transfer and the Dissemination of Technological Information Within the R\&D Organization. Cambridge, MA: MIT Press

Baldwin and Scott 1987 Market Structure and Technological Change, New York: Harwood Academic Publishers

Boroush, M. 2010 NSF Release New Statistics on Business Innovation, NSF Info Brief: 11300.

Cohen, W. 2010 'Fifty Years of Empirical Studies of Innovative Activity and Performance,' in B.H. Hall and N. Rosenberg, eds., Handbook of Economics of Innovation, Amsterdam: North Holland Elsevier.

Cohen, W. and S. Klepper 1996 "Firm Size and the Nature of Innovation within Industries: The Case of Process and Product R\&D," The Review of Economics and Statistics, 78(2): 23243

Hall, B. and J. Mairesse and P. Mohnen. 2010. “Measuring the Returns to R\&D”. in B.H. Hall and N. Rosenberg, eds., Handbook of Economics of Innovation, Amsterdam: North Holland Elsevier.

Jovanovic, B.,and G. M. MacDonald. 1994. "The Life Cycle of a Competitive 1ndustty", Journal of Political Economy 102(2): 322—47

Knott, A.M. 2008 "R\&D Returns Causality: Absorptive Capacity or Organizational IQ” Management Science 54 (12) 2054-2067

Knott, A.M. and C. Vieregger 2015 "An Empirical Test of Endogenous Firm Growth" SSRN Working paper 2382885.

Lentz, R. and D. Mortensen. 2008. An Empirical Model of Growth Through Product Innovation. Econometrica 76(6), 1317-1373.

Leonard-Barton, D. 1992. Core Capabilities and Core Rigidities: A Paradox in Managing New Product Development, Strategic Management Journal, 13, 111-125. 
Link, A. 1982. “An analysis of the composition of R\&D spending”, Southern Economic Journal, 342-349

Mansfield, E. 1981. Composition of R and D Expenditure: Relationship to size of firm, concentration, and innovative output. Review of Economics and Statistics 63:610-15.

Nelson, R. 1959. "The Simple Economics of Basic Scientific Research," Journal of Political Economy, 67: 297.

Pavitt, K., M. Robson and J. Townsend 1987. "The Size Distribution of Innovating Firms in the U.K.: 1945-1983”, The Journal of Industrial Economics, 55: 291-316.

Romer, P. 1990. Endogenous Technological Change. Journal of Political Economy, 98(5), 71-102.

Rosen, H. 1991 "Research and Development with Asymmetric Firm Sizes," RAND Journal of Economics, 22(3):

Scherer, F.M. 1965 "Firm Size, Market Structure, Opportunity and the Output of Patented Inventions”, American Economic Review, 55: 1097-1125

Scherer, FM 1991 "Changing Perspectives on the Firm Size Problem," in Z.J. Acs and D.B. Audretsch, (eds.), Innovation and Technological Change: An International Comparison, Ann Arbor: University of Michigan Press, 24-38.

Scherer, FM and D. Harhoff. 2000. Technology policy for a world of skew-distributed outcomes. Research Policy 29, 559-566.

Scherer, FM and D. Ross 1990. Industrial market structure and economic performance (3rd ed.) Boston: Houghton Mifflin

Schumpeter, J. 1942 Capitalism, Socialism, and Democracy, New York: Harper and Row.

Stevens, G. and J. Burley.1997. “3,000 Raw Ideas Equals 1 Commercial Success!” ResearchTechnology Management, 40,(3) :

Syverson, C. 2011. What Determines Productivity. Journal of Economic Literature 49(2), 326-365.

Thompson, P. 1996. Technological Opportunity and the Growth of Knowledge: A

Schumpeterian Approach to Measurement. Journal of Evolutionary Economics 6(1), 77-97 
TABLE 1. Data Summary

Observations $=2030$

\begin{tabular}{|l|r|r|}
\hline Variable & Mean & Std. Dev. \\
\hline \hline Sales (4-year average, log) & 11.80 & 2.14 \\
\hline Employees (4-year average, log) & 6.19 & 1.90 \\
\hline R\&D (4-year average, log) & 8.60 & 1.95 \\
\hline spillover (log) & 12.45 & 4.57 \\
\hline R\&D Intensity (4-year average) & 0.26 & 2.99 \\
\hline RQ (4-year average) & 0.26 & 0.05 \\
\hline SQ (4-year average) & -0.02 & 0.02 \\
\hline Basic R\&D (4-year average, percent) & 4.20 & 9.07 \\
\hline Applied R\&D (4-year average, percent) & 14.71 & 17.81 \\
\hline Development R\&D (4-year average, percent) & 81.09 & 20.83 \\
\hline Process R\&D (4-year average, percent) & 0.58 & 0.37 \\
\hline Product R\&D (4-year average, percent) & 0.77 & 0.32 \\
\hline Service R\&D (4-year average, percent) & 0.33 & 0.37 \\
\hline R\&D Incremental (4-year average, percent) & 76.88 & 25.61 \\
\hline R\&D New-to-Market (4-year average, percent) & 12.02 & 19.08 \\
\hline R\&D New-to-Firm (4-year average, percent) & 11.10 & 17.38 \\
\hline Patents granted 2008 & 15.56 & 116.75 \\
\hline
\end{tabular}


TABLE 2. Main Effects of Firm Size

\begin{tabular}{|l|c|c|c|c}
\hline & \multicolumn{4}{|c}{ Dependent Variable } \\
\hline & $\ln (\mathrm{R \& D})$ & $\ln (\mathrm{R \& D})$ & $\mathrm{RQ}$ & RQ \\
\hline \hline & & & & \\
\hline $\ln$ (Sales) & $\mathbf{0 . 6 2 1}$ & & $\mathbf{0 . 0 1 4}$ & \\
\hline & 0.019 & & 0.001 & \\
\hline & & & & \\
\hline $\ln$ (Employees) & & $\mathbf{0 . 7 1 7}$ & & $\mathbf{0 . 0 0 9}$ \\
\hline & & 0.018 & & 0.001 \\
\hline & & & & \\
\hline Constant & 1.263 & 4.152 & $\mathbf{0 . 0 9 4}$ & $\mathbf{0 . 2 1 0}$ \\
\hline & 0.219 & 0.111 & 0.006 & 0.004 \\
\hline & & & & \\
\hline & & & & \\
\hline R-squared & 0.463 & 0.488 & 0.412 & 0.120 \\
\hline \hline & 2030 & 2030 & 2030 & 2030 \\
\hline \hline
\end{tabular}

All variables are four year (2008-2011) means

Robust std error below coefficients 
TABLE 3. Impact of Scale on Choice of Uni-dimensional R\&D Strategy

\begin{tabular}{|c|c|c|c|c|c|c|c|c|c|c|c|c|c|c|c|c|c|c|}
\hline & \multicolumn{18}{|c|}{ Dependent Variable } \\
\hline & \%basic & \%basic & $\begin{array}{c}\% \\
\text { applied }\end{array}$ & $\begin{array}{c}\% \\
\text { applied }\end{array}$ & $\begin{array}{c}\% \\
\text { Develo } \\
\text { pment }\end{array}$ & $\begin{array}{c}\% \% \\
\text { Develo } \\
\text { pment }\end{array}$ & $\begin{array}{l}\text { probx } \\
\text { product }\end{array}$ & $\begin{array}{c}\text { prob: } \\
\text { product }\end{array}$ & $\begin{array}{l}\text { probx } \\
\text { service }\end{array}$ & $\begin{array}{l}\text { probx } \\
\text { service }\end{array}$ & $\begin{array}{c}\text { probx } \\
\text { process }\end{array}$ & $\begin{array}{c}\text { probx } \\
\text { process }\end{array}$ & $\begin{array}{l}\text { New to } \\
\text { market- } \\
\text { \%sales }\end{array}$ & $\begin{array}{l}\text { New to } \\
\text { market- } \\
\text { \%sales }\end{array}$ & $\begin{array}{l}\text { New to } \\
\text { firm- } \\
\text { \%osales }\end{array}$ & $\begin{array}{l}\text { New to } \\
\text { firm- } \\
\text { \%sales }\end{array}$ & $\begin{array}{c}\text { incre } \\
\text { mental- } \\
\text { \%sales }\end{array}$ & $\begin{array}{c}\text { incre } \\
\text { mental- } \\
\text { \%sales }\end{array}$ \\
\hline 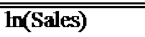 & 0.760 & & 0.221 & & -0.338 & & 0.086 & & $\overline{\mathbf{0 . 1 7 7}}$ & & 0.219 & & -1.047 & & -0329 & & 1.624 & \\
\hline $\mathbf{S E}$ & 0.177 & & 0.242 & & 0.275 & & 0.043 & & 0.022 & & 0.032 & & 0.264 & & 0.249 & & 0.306 & \\
\hline In(Employees) & & 0.909 & & 0.280 & & -0.445 & & 0.069 & & 0.229 & & 0.278 & & -0.756 & & -0.280 & & 1.336 \\
\hline SE & & 0.199 & & 0.272 & & 0.310 & & 0.048 & & 0.026 & & 0.038 & & 0.299 & & 0.279 & & 0.345 \\
\hline Constant & -11.704 & $\mathbf{8 . 3 6 4}$ & 8.386 & 9.248 & 88.680 & 87.447 & 1.614 & 2.187 & -1.802 & -1.129 & 08865 & 0.010 & 19.629 & 11.940 & 10.441 & 8.283 & 59.359 & 70.256 \\
\hline $\mathbf{S E}$ & 2.177 & 1346 & 2.917 & 1.779 & 3321 & 2.024 & 0.503 & 0.302 & 0.266 & 0.162 & 0.364 & 0.220 & 3.177 & 1.940 & 3.000 & 1.815 & 3.667 & 2.231 \\
\hline$\overline{\mathrm{R} 2}$ & 0.002 & 0.002 & 0.000 & 0.000 & 0.000 & 0.000 & 0.004 & 0.002 & 0.024 & 0.031 & 0.029 & 0.034 & 0.001 & 0.000 & 0.000 & 0.000 & 0.002 & 0.001 \\
\hline observations & 2030 & 2030 & 2030 & 2030 & 2030 & 2030 & 2030 & 2030 & 2030 & 2030 & 2030 & 2030 & 2030 & 2030 & 2030 & 2030 & 2030 & 2030 \\
\hline
\end{tabular}


TABLE 4. Impact of Uni-dimensional R\&D Strategy On RQ

\begin{tabular}{|c|c|c|c|c|c|c|c|c|c|}
\hline \multirow[t]{4}{*}{ Dependent variable $=$ RQ } & & & & 1 & & & & & \\
\hline & & & & & & & & & \\
\hline & \multicolumn{9}{|c|}{ strategy } \\
\hline & \%basic & \% appliex & $\begin{array}{c}\text { \% Develop } \\
\text { ment }\end{array}$ & $\mathbf{P}$ (product) & P(service) & P(process) & $\begin{array}{l}\text { New to } \\
\text { market- } \\
\text { \%sakes }\end{array}$ & $\begin{array}{c}\text { New to firm- } \\
\text { \%sales }\end{array}$ & $\begin{array}{c}\text { incremental } \\
\text { \%saks }\end{array}$ \\
\hline \multirow[t]{2}{*}{ strategy } & -0.00060 & -0.00130 & 0.00100 & 0.08500 & 0.06100 & 0.07200 & -0.00100 & 0.00060 & 0.00060 \\
\hline & 0.00040 & 0.00020 & 0.00020 & 0.01400 & 0.01200 & 0.01300 & 0.00010 & 0.00025 & 0.00010 \\
\hline \multirow[t]{2}{*}{ strategy $y^{*} \ln ($ sakes) } & 0.00004 & 0.00010 & -0.00009 & -0.00700 & -0.00700 & -0.00700 & 0.00007 & -0.00007 & -0.00003 \\
\hline & 0.00004 & 0.00002 & 0.00002 & 0.00100 & 0.00090 & 0.00100 & 0.00001 & 0.00002 & 0.00001 \\
\hline \multirow[t]{2}{*}{ ln(sakes) } & 0.014 & 0.013 & 0.022 & 0.020 & 0.018 & 0.019 & 0.013 & 0.015 & 0.016 \\
\hline & 0.000 & 0.001 & 0.001 & 0.001 & 0.001 & 0.001 & 0.000 & 0.000 & 0.001 \\
\hline \multirow[t]{2}{*}{ constant } & 0.097 & 0.116 & 0.008 & 0.028 & 0.062 & 0.047 & 0.114 & 0.088 & 0.052 \\
\hline & 0.005 & 0.006 & 0.016 & 0.011 & 0.006 & 0.009 & 0.005 & 0.005 & 0.012 \\
\hline R-squared & 0.412 & 0.421 & 0.420 & 0.423 & 0.442 & 0.423 & 0.434 & 0.417 & 0.430 \\
\hline Net coefficient on scak & 0.0142 & 0.0127 & 0.0219 & 0.0130 & 0.0110 & 0.0120 & 0.0131 & 0.0149 & 0.0164 \\
\hline
\end{tabular}


TABLE 5. Strategy Archetypes

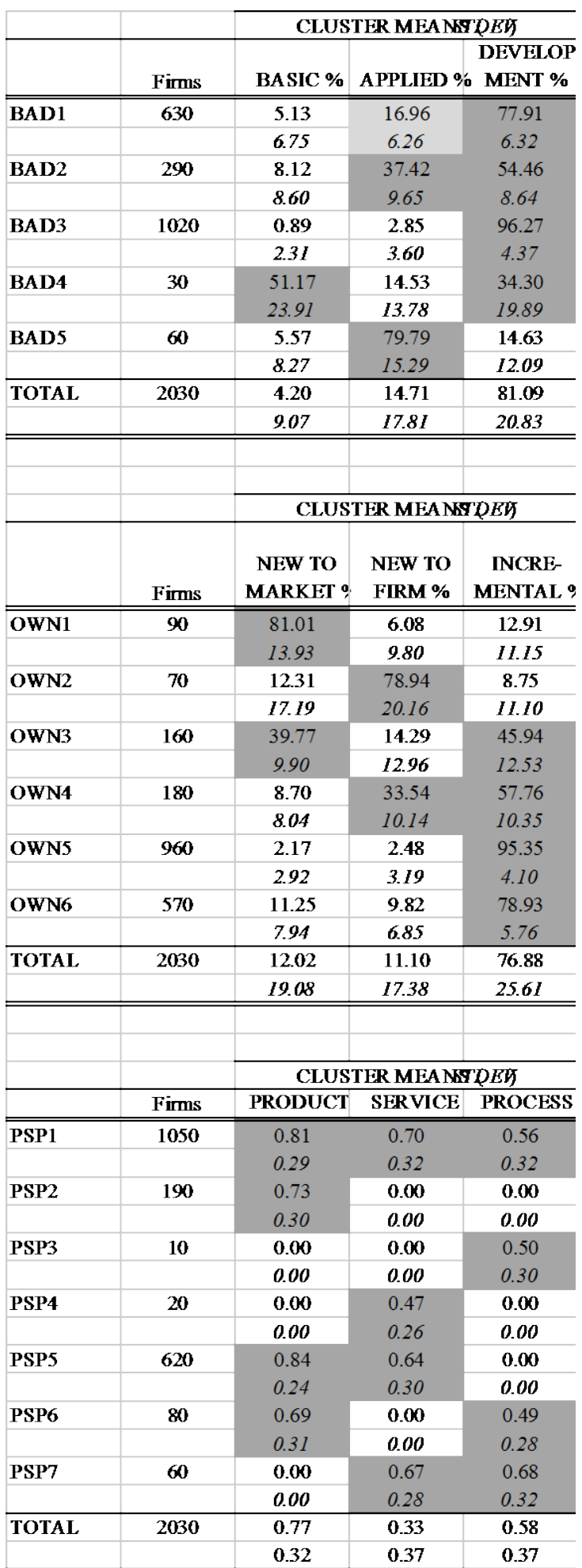


TABLE 6. Impact of Scale on Choice of R\&D Strategy Archetypes

\begin{tabular}{|c|c|c|c|c|c|c|c|c|c|c|c|c|c|c|c|c|c|c|}
\hline & \multicolumn{18}{|c|}{ Dependent Variatle } \\
\hline & BAD1 & BAD2 & BAD3 & BAD4 & BAD5 & OWN1 & OWN2 & OWN3 & OWN4 & OWN5 & OWN6 & PSP1 & PSP2 & PSP3 & PSP4 & PSP5 & PSP6 & PSP7 \\
\hline $\ln$ (Sales) & 0041 & 0018 & -0.026 & 0.067 & -0.130 & -0.231 & -0.123 & -101 & -0006 & 0.081 & -0001 & 0.201 & -220 & -0081 & -0092 & -105 & -207 & -0046 \\
\hline SE & 0.022 & 0.031 & 0.021 & 0.104 & 0.079 & 0.091 & 0.068 & 0.042 & 0.038 & 0.021 & 0.022 & 0.022 & 0.036 & 0.091 & 0.084 & 0.022 & 0.049 & 0.078 \\
\hline Constant & -1.282 & -2.00 & 0.301 & -3.325 & -1960 & 0.488 & $-1.8 \%$ & -1.272 & -2247 & -1.668 & 0.918 & -2.295 & 0.211 & -4.266 & -3.354 & 0.408 & 0.787 & -3019 \\
\hline SE & 0.271 & 0369 & 0.250 & 1208 & 0901 & 1.001 & 0.782 & 0.488 & 0.452 & 0.250 & 0.269 & 0.263 & 0.407 & 1.087 & 0.985 & 0.263 & 0.559 & 0920 \\
\hline Prob $>$ chi2 2 & 0.070 & 0563 & 0220 & 0521 & 0101 & 0.011 & 0.071 & 0.017 & 0865 & 0.000 & 0958 & 0.000 & 0.000 & 0372 & 0274 & 0.000 & 0.000 & 0555 \\
\hline $\mathbf{N}$ & 2030 & 2030 & 2030 & 2030 & 2030 & 2030 & 2030 & 2030 & 2030 & 2030 & 2030 & 2030 & 2030 & 2030 & 2030 & 2030 & 2030 & 2030 \\
\hline
\end{tabular}


TABLE 7. Impact of R\&D Strategy Archetypes on RQ

\begin{tabular}{|c|c|c|c|c|c|c|c|c|c|c|c|c|c|c|c|c|c|c|}
\hline \multicolumn{19}{|c|}{ Observations =2030 (rumded) } \\
\hline \multicolumn{19}{|c|}{ Depol cat varib $k=\mathrm{KQ}$} \\
\hline & \multicolumn{18}{|c|}{ Strategy Archetype } \\
\hline & BAD1 & BAD2 & BAD3 & BAD4 & BAD5 & OWN1 & OWN2 & OWN3 & OWN4 & OWN5 & OWN6 & PSP1 & PSP2 & PSP3 & PSP4 & PSP5 & PSP6 & PSP7 \\
\hline \multirow[t]{2}{*}{ strategy } & -0.001 & 0.005 & 0.000 & -0.012 & -0.003 & -0.026 & -0.008 & -0.002 & -0066 & 0.010 & -0.002 & $-\infty \mathbf{\omega}^{2}$ & 0.004 & -0.007 & -0.004 & 0.010 & -0.005 & -0.013 \\
\hline & 0.002 & 0.002 & 0.002 & 0.006 & 0.007 & 0.005 & 0.005 & 0.003 & 0003 & 0.002 & 0.002 & 0.001 & 0.003 & 0.008 & 0.008 & 0.002 & 0.004 & 0.004 \\
\hline \multirow[t]{2}{*}{$\ln$ (sales) } & 0.014 & 0.014 & 0.014 & 0.014 & 2014 & 0.014 & 0.014 & 0.014 & 2014 & 0.014 & 0.014 & 0.015 & 0.014 & $\mathbf{0 . 0 1 4}$ & 0.014 & 0.015 & 0.014 & 0.014 \\
\hline & 0.001 & 0.000 & 0.001 & 0.001 & 0.001 & 0.001 & 0.001 & 0.001 & 0001 & 0.001 & 0.001 & 0.001 & 0.001 & 0.001 & 0.001 & 0.001 & 0.001 & 0.001 \\
\hline \multirow[t]{2}{*}{ constrant } & 0.095 & 0.094 & 0.094 & 0.095 & $\operatorname{ecs} 4$ & 0.098 & 0.095 & 0.096 & 2095 & $\mathbf{0 . 0 9 2}$ & 0.095 & 0.64 & 0.093 & e.e94 & 0.64 & ¿.e89 & 0.695 & 0.094 \\
\hline & 0.006 & 0.006 & 0.006 & 0.006 & 0.006 & 0.006 & 0.006 & 0.006 & 0.006 & 0.006 & 0.006 & 0.006 & 0.006 & 0.006 & 0.006 & 0.006 & 0.006 & 0.006 \\
\hline R-squared & 0.412 & 0.413 & 0.412 & 0.413 & 0.412 & 0.424 & 0.413 & 0.412 & 0.413 & 0.422 & 0.412 & 0.417 & 0.412 & 0.412 & 0.412 & 0.421 & 0.412 & 0.414 \\
\hline
\end{tabular}


TABLE 8. Main Effects of Scale on Spillovers and SQ

\begin{tabular}{|c|c|c|c|c|}
\hline & \multicolumn{4}{|c|}{ Dependent Variable } \\
\hline & $\ln$ (uppersum) & persum) & SQ & SQ \\
\hline $\ln$ (Sales) & -0.652 & & 0.004 & \\
\hline SE & 0.045 & & 0.000 & \\
\hline $\ln$ (Employees) & & -0.743 & & $\mathbf{0 . 0 0 3}$ \\
\hline SE & & 0.051 & & 0.000 \\
\hline Constant & 20.144 & 17.056 & -0.074 & -0.040 \\
\hline SE & 0.543 & 0.329 & 0.002 & 0.001 \\
\hline $\mathrm{R} 2$ & 0.093 & 0.095 & 0.319 & 0.095 \\
\hline $\mathrm{N}$ & 2030 & 2030 & 2030 & 2030 \\
\hline
\end{tabular}


FIGURE 1. Net Effect of Scale on RQ for Horizon Strategies
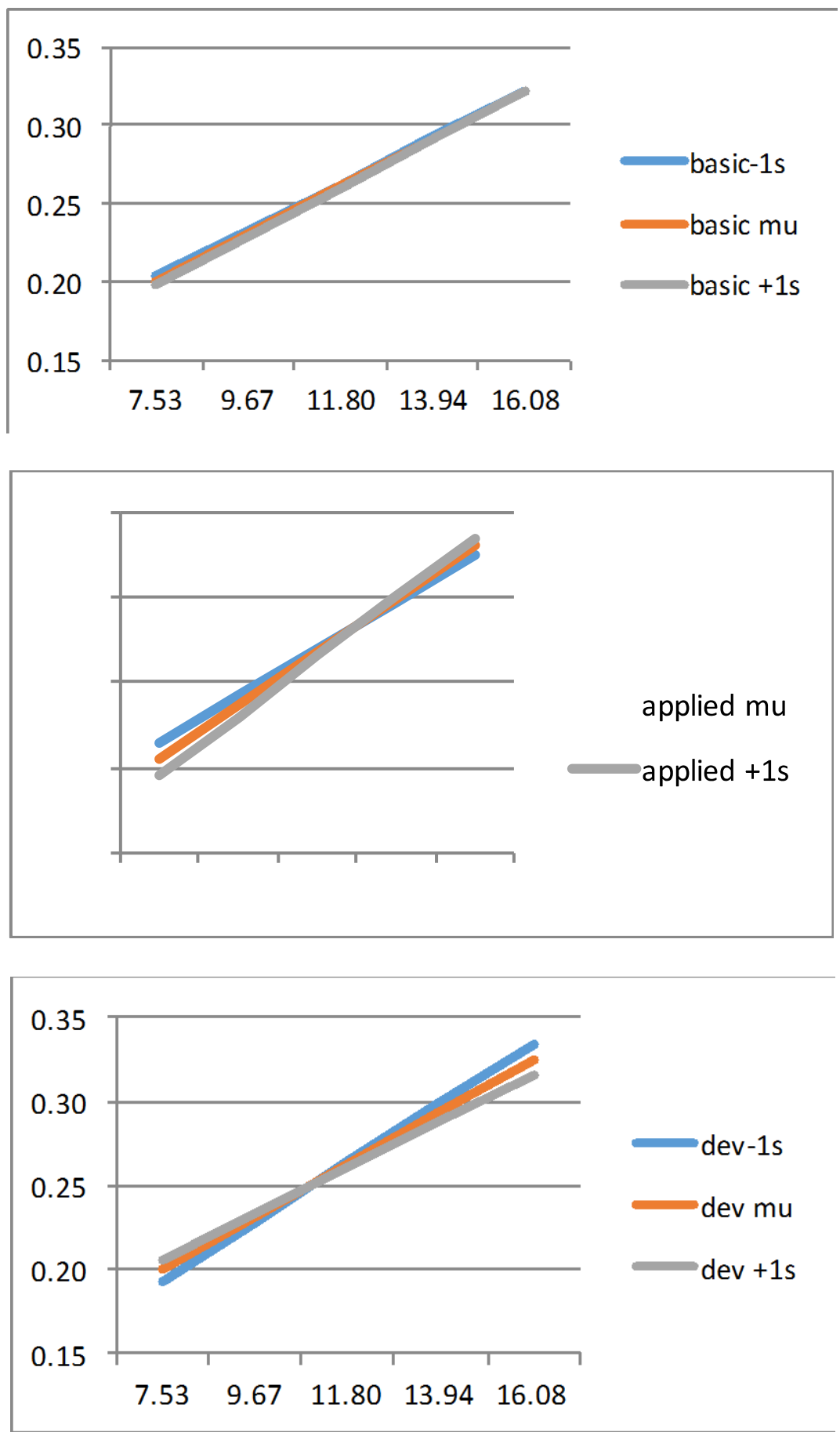
FIGURE 2. Relative Contributions of Own R\&D and Spillovers to Revenues

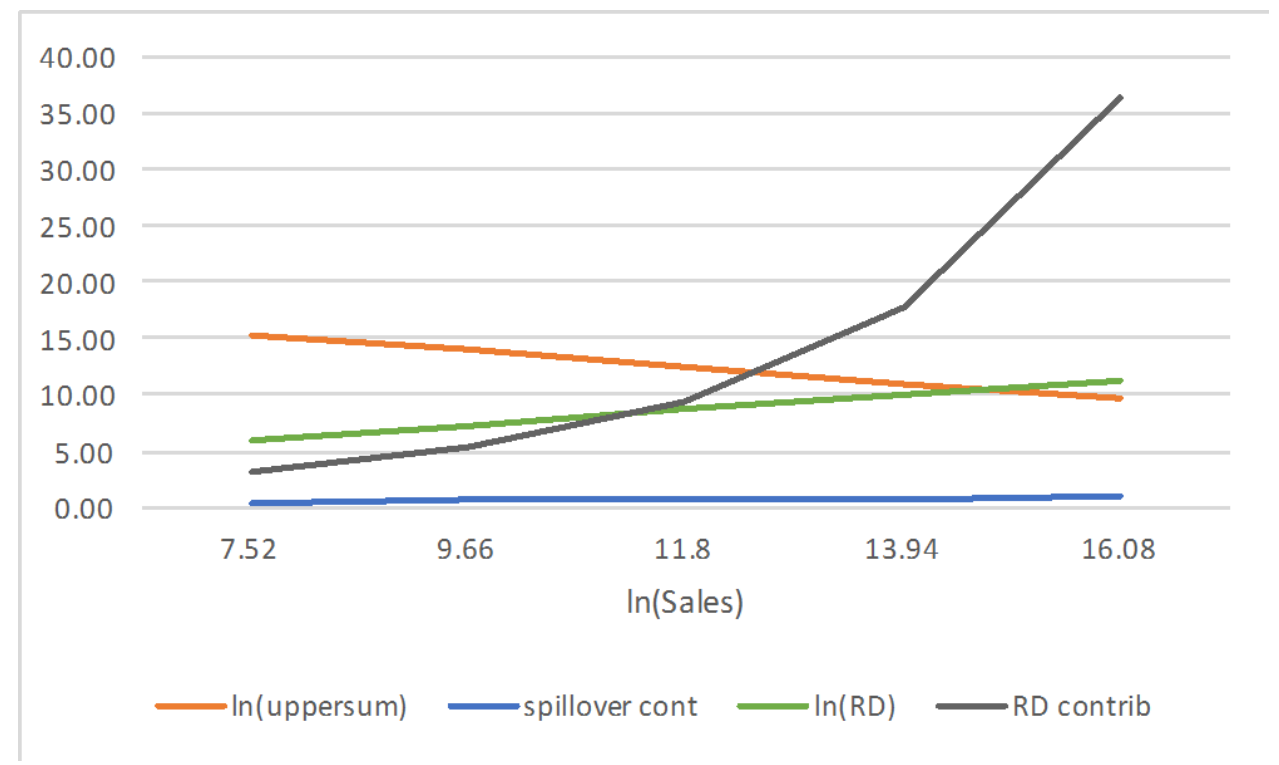

